\title{
BURNING OF RADIOACTIVE PROCESS SOLVENT
}

\author{
D. W. Tharin, Jr.
}
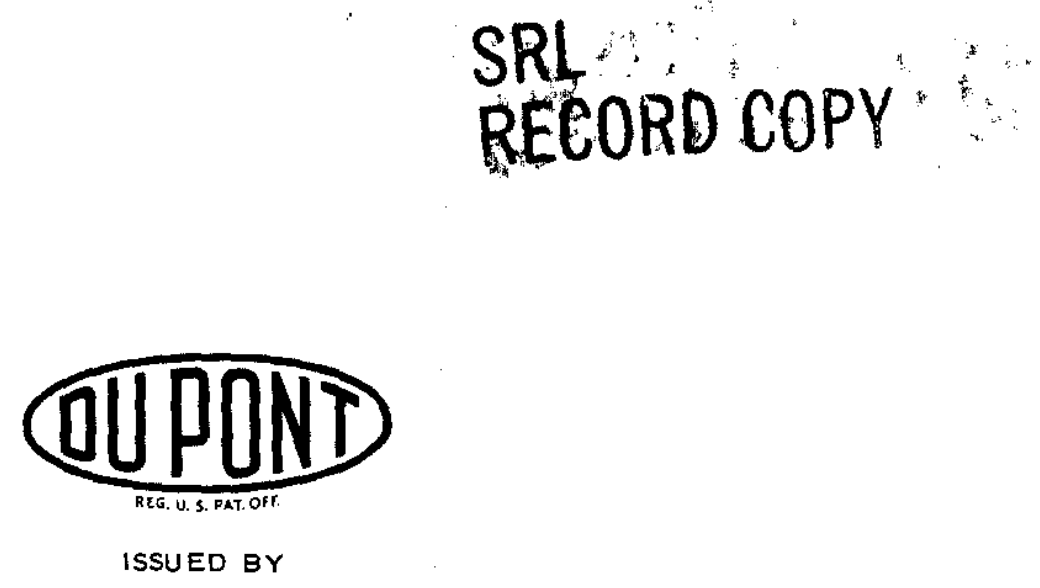

Savannah River Laboratory

Aiken, South Carolina 


\section{LEG A L NOTICE}

This report was prepared as an account of Government sponsored work. Neither the United States, nor the Commission, nor any person acting on behalf of the Commission:

A. Makes any warranty or representation, expressed or implied, with respect to the accuracy, completeness, or usefulness of the information contained in this report, or that the use of any information, apparatus, method, or process disclosed in this report may not infringe privately owned rights; or

B. Assumes any liabilities with respect to the use of, or for damages resulting from the use of any information, apparatus, method, or process disclosed in this report.

As used in the above, "person acting on behalf of the Commission" includes any employee or contractor of the Commission, or employee of such contractor, to the extent that such employee or contractor of the Commission, or employee of such contractor prepares, disseminates, or provides access to, any information pursuant to his employment or contract with the Commission, or his employment with such contractor.

Printed in USA. Price $\$ 1.00$

Avallable from the Clearlnghouse for Federal Sclentific and Technical Information, National Bureau of Standards,

U. S. Department of Commerce, Springfleld, Virginia 


\title{
BURNING OF RADIOACTIVE PROCESS SOLVENT \\ by
}

D. Whitney Tharin, Jr.

\author{
Approved by \\ E. B. Sheldon, Superintendent \\ - Separations Technology Section \\ Works Technical Department \\ Savannah River Plant
}

February 1965

\author{
E. I. DU PONT DE NEMOURS \& COMPANY \\ SAVANNAH RIVER LABORATORY \\ AIKEN, SOUTH CAROLINA \\ CONTRACT AT(07.2).1 WITH THE \\ UNITED STATES ATOMIC ENERGY COMMISSION
}




\begin{abstract}
Spent solvent from radiochemical separations processes is accumulated and burned in burlal ground facilities. Between mid-1955 and February 1964, 290,000 gallons were stored or burned with negligible release of radionuclides.
\end{abstract}




\section{CONTENTS}

$\underline{\text { Page }}$

List of Tables and Figures. . . . . . . . . . . 4

INTRODUCTION. . . . . . . . . . . . . . . . 5

SUMMARY . . . . . . . . . . . . . . . . 5

DISCUSSION. . . . . . . . . . . . . . 6

Storage Tanks. . . . . . . . . . . . . . 6

Burning Apparatus and Procedure. . . . . . . . 9

Contamination Control Measures .......... 10

Quantities Handied . . . . . . . . . . . . 11

Attempts at Improvement. . . . . . . . . . . 11

Purlfication and Reuse.............. 11

Purification for Unrestricted Burning. . . . . . 13

Burning Methods ............. 14

Residue Disposal. . . . . . . . . . 16 


\section{LIST OF TABLES AND FIGURES}

Table $\underline{\text { Page }}$

I Solvent Storage Tanks. . . . . . . . . . . 6

II Spent Solvent Inventory $(2 / 29 / 64)$ and Radioactivity. . . 8

II Distillation of Spent Solvent at Atmospheric Pressure. . . 13

\section{Figure}

1 Spent Solvent Storage and Burning Fac1lities...... . 7

2 Solvent Burning Facility . . . . . . . . . . . 9

3 Spent Solvent in Burial Ground . . . . . . . . . . . 12

4 Oil-Burning Salamander .............. 14

5 Apparatus for Underground Burning Test . . . . . . . 15 


\title{
BURNING OF RADIOACTIVE PROCESS SOLVENT
}

\author{
INTRODUCTION
}

In the radiochemical separations processes at the Savannah River Plant, organic solvent is degraded by exposure to radiation and by accumulation of radionuclides. When solvent [typically $30 \%$ tributyl phosphate (TBP) in kerosene with residual uranium, plutonium, and fission products] is no longer usable in the process, it is transferred to storage tanks at the burial ground. Since 1956 some of the stored solvent has been burned, with its volatile combustion products dispersed to the atmosphere and its residue buried.

This method of disposal was selected because (1) most of the solvent's radioactivity remains in the relatively small, immobile residue that is left after the bulk of the solvent has been oxidized and dispersed to the atmosphere, and (2) capital costs and operating expenses are low. However, the method has potential disadvantages: it disperses some radioactive materlal and smoke to the atmosphere, and it contaminates the burning pit with the residue.

The process has been evaluated by comparing its release of radioactivity to the environment with that released by other Savannah River processes. In 1962 the radioactivity released to the atmosphere by solvent burning was estimated to be less than $0.1 \%$ as much alpha and $1.2 \%$ as much beta-gamma as was released from the stack of a separations plant; that which was buried (as nearly insoluble residue) was only $8.8 \%$ as much alpha and $0.9 \%$ as much beta-gamma as was sent to the seepage basins for the same area. Any radionuclides that were leached from the residue by ground water were subject to ion exchange with the so11.

The spent solvent storage facilities and the design and development of disposal equipment are presented in this report.

\section{SUMM ARY}

of the 290,000 gallons of spent solvent sent to the burial ground through February 1964, 170,000 gallons were burned, leaving 120,000 gallons in storage. The present storage capacity is 162,000 gallons.

Solvent is burned by adding it slowly to a fire in a large open pan. Although large quantities of black smoke are created, release of radionuclides to the atmosphere is neglig1ble. More than $99.9 \%$ of the 
main contaminant, ${ }^{108} \mathrm{Ru}$, remains in the residue and is buried. Concentrations of uranium or plutonium above their limits of detection are not normally found in the smoke. So far, efforts toward smoke abatement have been unsuccessful, but are continuing.

\section{DISCUSSION}

\section{STORAGE TANKS}

The solvent storage facility in the burlal ground consists of elghteen tanks having a total capacity of 198,700 gallons, with individual capacities ranging from 3200 to 27,200 gallons (allowing for 10-inch freeboard)(see Table I).

The first four tanks that were installed are retired from service, but are usable for an emergency. The present capac1ty (162,400 gallons) was $70 \%$ ut1lized (114,600 gallons) at the end of February 1964. How-

\section{TABLE I}

\section{Solvent Storage Tanks}

\begin{tabular}{|c|c|c|c|c|c|}
\hline \multirow[b]{2}{*}{ Tank No. } & \multicolumn{2}{|c|}{ Tank Dimensions, ft } & \multicolumn{2}{|c|}{ Capac1ty (a) } & \multirow[b]{2}{*}{ Date Installed } \\
\hline & Diameter & Length & Inches & allions & \\
\hline${ }_{1}(b)$ & 8.0 & 28.5 & 86 & 10,300 & Aus. 1955 \\
\hline (b) & 8.0 & 28.5 & 86 & 10,300 & Aug. 1955 \\
\hline $3^{(b)}$ & 8.0 & 28.5 & 86 & 10,300 & Aug. 1955 \\
\hline $4(b)$ & 8.0 & 14.0 & 72 & 5,400 & Aug. 1955 \\
\hline 5 & 10.5 & 38.5 & 116 & 24,600 & Sept. 1955 \\
\hline 6 & 10.5 & 38.5 & 116 & 24,600 & Apr11 1956 \\
\hline 7 & 8.5 & 18.0 & 92 & 7,800 & Apr11 1956 \\
\hline 8 & 8.5 & 18.0 & 92 & 7,800 & Apr11 1956 \\
\hline 9 & 8.0 & 20.0 & 89 & 7,400 & March 1959 \\
\hline 10 & 8.0 & 20.0 & 89 & 7,400 & March 1959 \\
\hline 11 & 8.0 & 20.0 & 89 & 7,400 & March 1959 \\
\hline 12 & 8.0 & 20.0 & 89 & 7,400 & March 1959 \\
\hline 13 & 10.0 & 23.0 & 110 & 13,800 & Aug. 1960 \\
\hline 14 & 11.0 & 38.0 & 122 & 27,200 & Aug. 1960 \\
\hline 15 & 7.5 & 32.0 & 79 & 10,300 & Jan. 1961 \\
\hline 16 & 7.5 & 32.0 & 79 & 10,300 & Jan. 1961 \\
\hline 17 & 8 & 9 & 86 & 3,200 & July 1962 \\
\hline 18 & 8 & 9 & 86 & 3,200 & July 1962 \\
\hline & & & & 198,70 & \\
\hline
\end{tabular}

(a) W1th 10-1nch freeboard.

(b) Now retired in place, but usable in emergency.

(c) Including retired Tanks 1 through 4. 
ever, many of the tanks that are only partially full have been aging for several years, and it would be imprudent to add fresh solvent of a high contamination level to these tanks. Hence, the figure for total utilization of the tanks is deceptively low from a practical standpoint.

The tanks were installed at various times since 1955 (see Table I), and are buried in relatively high ground with two to three feet of earth cover. All are connected to an above-ground pipeline that permits transfer to the feed tank of the burning apparatus (see Figure 1 ). Special temporary piping is required for intertank transfers.

All of the tanks are mild steel and were surplus or salvage from this or other AEC installations. Some were coated on the outside with an asphalt-base material to prevent corrosion; all were originally painted, but the paint was not repalred on all of them before they were
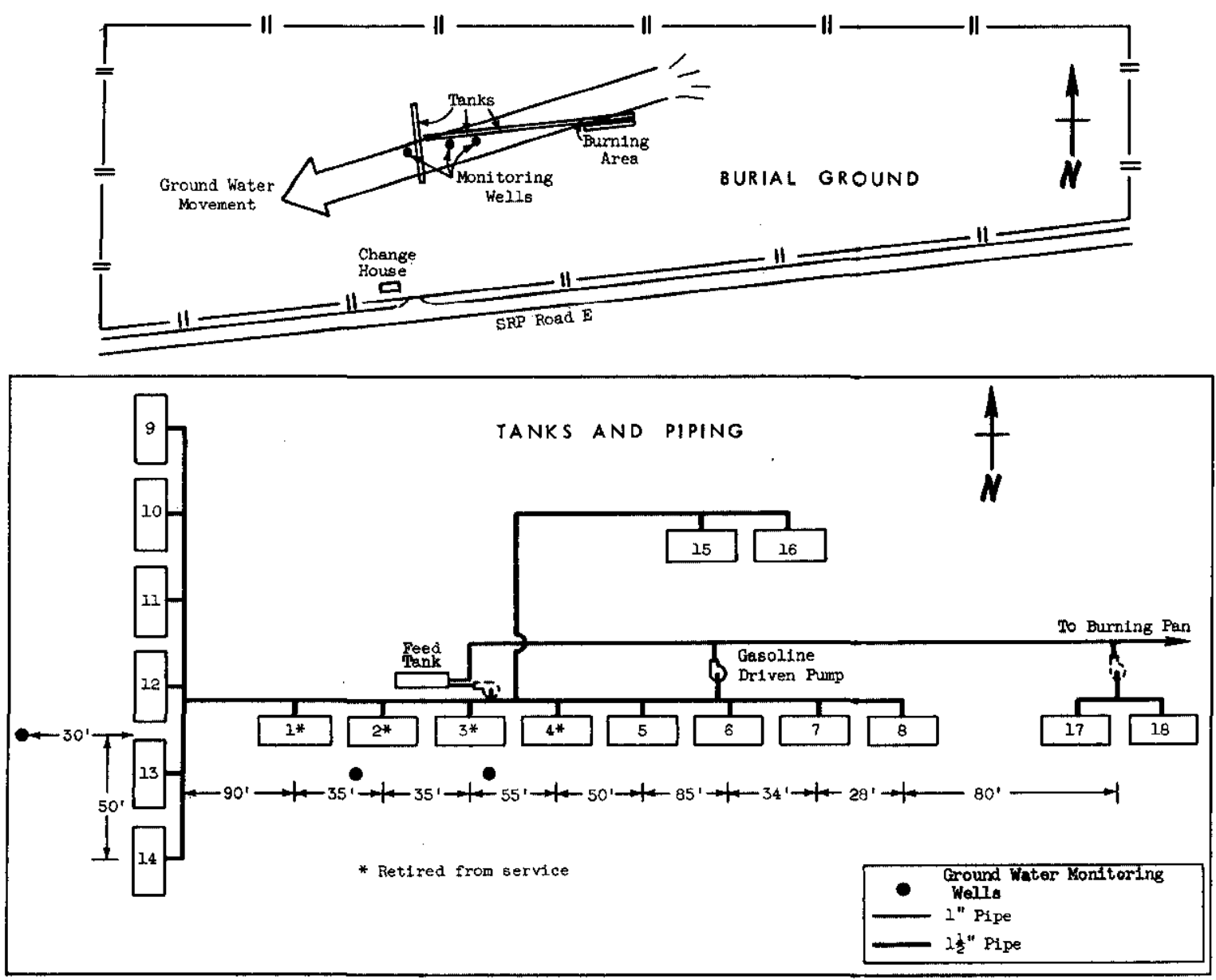

FIG. I SPENT SOLVENT STORAGE AND BURNING FACILITIES 
buried. "Audigage"* thickness measurements of tanks 9 through 12 before their installation averaged 0.613 inch for three of the tanks and 0.543 inch for the other one. Five years was the estimated satisfactory service life of the first four tanks when they were instalied, provided the solvent was noncorrosive. However, after nine years of use no leaks have been detected by level measurements and ground water monltoring welis. By comparison, underground storage tanks for fuel 011 and gasoline have a I1fe expectancy of 25 to 40 years according to petroleum products dealers in this geographic area.

Storage tank contents are sampled perlod1cally. Table II gives the most recent radioactivity analyses of solvent in the storage tanks. An aqueous layer forms at the bottom of each tank from (1) water that is entrained when solvent is discharged from the process, (2) condensate from steam jetting of solvent from process vessels, (3) water used in the burial ground to prime the solvent pump, and (4) caustic solutions added to keep the water alkaline. The volume of water in each tank varies from 100 to 1000 gallons; solvent volumes reported are actually total liquid volumes including water.

* Reg1stered trademark of Branson Instruments, Inc., Stamford, Conn.

TABLE II

Spent Solvent Inventory $(2 / 29 / 64)$ and Radioact1vity

Content Alpha Beta Gamma

(2/29/64), Activity, Activity, Activity, Date

Tank No. gal $d /(\mathrm{mIn})(\mathrm{mI}) \mathrm{c} /(\mathrm{mIn})(\mathrm{mI}) \mathrm{c} /(\mathrm{mIn})(\mathrm{mI})$ Analyzed

\begin{tabular}{|c|c|c|c|c|c|}
\hline 1 & $100(a)$ & - & - & - & - \\
\hline 2 & $2,100(a)$ & - & - & - & - \\
\hline 3 & 2,400 (a) & - & - & - & - \\
\hline 4 & $100(a)$ & - & - & - & - \\
\hline 5 & 24,600 & $1.3 \times 10^{4}$ & $2.9 \times 10^{4}$ & $4.2 \times 10^{3}$ & $12 / 5 / 63$ \\
\hline 6 & 10,800 & 824 & $1.8 \times 10^{4}$ & $2.5 \times 10^{3}$ & $12 / 5 / 63$ \\
\hline 7 & 2,400 & 230 & $1.0 \times 10^{4}$ & $1.5 \times 10^{3}$ & $12 / 5 / 63$ \\
\hline 8 & 6,700 & $1.5 \times 10^{4}$ & $8.5 \times 10^{8}$ & $2.5 \times 10^{3}$ & $12 / 5 / 63$ \\
\hline 9 & 7,000 (b) & - & - & - & - \\
\hline 10 & $7,100(\mathrm{~b})$ & - & - & - & - \\
\hline 11 & 6,700 (b) & - & - & - & - \\
\hline 12 & $5,100^{(b)}$ & - & - & - & - \\
\hline 13 & 7,100 & $3.1 \times 10^{3}$ & $2.9 \times 10^{4}$ & $4.4 \times 10^{3}$ & $12 / 5 / 63$ \\
\hline 14 & 24,100 & $5.5 \times 10^{3}$ & $6.7 \times 10^{3}$ & $8.8 \times 10^{3}$ & $12 / 5 / 63$ \\
\hline 15 & 2,500 & $2.5 \times 10^{3}$ & $4.8 \times 10^{4}$ & $6.8 \times 10^{4}$ & $12 / 12 / 62$ \\
\hline 16 & 9,300 & $1.2 \times 10^{4}$ & $3.3 \times 10^{3}$ & $5.8 \times 10^{3}$ & $12 / 5 / 63$ \\
\hline 17 & 500 & $4.2 \times 10^{3}$ & $3.7 \times 10^{8}$ & $2.7 \times 10^{3}$ & $12 / 12 / 62$ \\
\hline 18 & 500 & 20 & 47 & 359 & $12 / 12 / 62$ \\
\hline
\end{tabular}

(a) Heel, mostiy water.

(b) New material; not sampled. 


\section{BURNING APPARATUS AND PROCEDURE}

A predetermined volume of solvent is pumped from its storage tank into an above-ground feed tank (about 1400-gal capacity) from which it flows by gravity to the burning pan, passing through a device to prevent flashback. A small quantity of spent solvent or clean diesel fuel is admitted to the burning pan and ignited; then solvent flow from the feed tank is regulated by operating a line valve to yield a slow, continuous flow to the burning pan. Resldue is emptied from the pan into the ditch and is subsequentiy buried, as are used burning pans.

The device to prevent flashback from the burning pan through the feed pipe to the tank is a 55-galion drum about two-thirds full of water. Solvent enters at the bottom and rises through the water to an overflow plpe that is part of the feed line to the burning pan.

Design of the burning pans has varied. Earlier versions were mild steel and shallow, only 6 to 12 inches deep. These pans did not last long because they lay uncovered in the bottom of the burning ditch and corroded severely from the intense heat and the phosphoric acid that formed when rain water combined with oxldation products of TBP in the residue. One pan fabricated of stainless steel gave longer service, but not enough to justify its higher cost. Several discarded denitrator pots of stalnless steel were later used under a metal roof (see Figure 2). Recently, a large mild-steel pan ( $8 \mathrm{ft} \times 8 \mathrm{ft} \times 4 \mathrm{ft}$ deep)

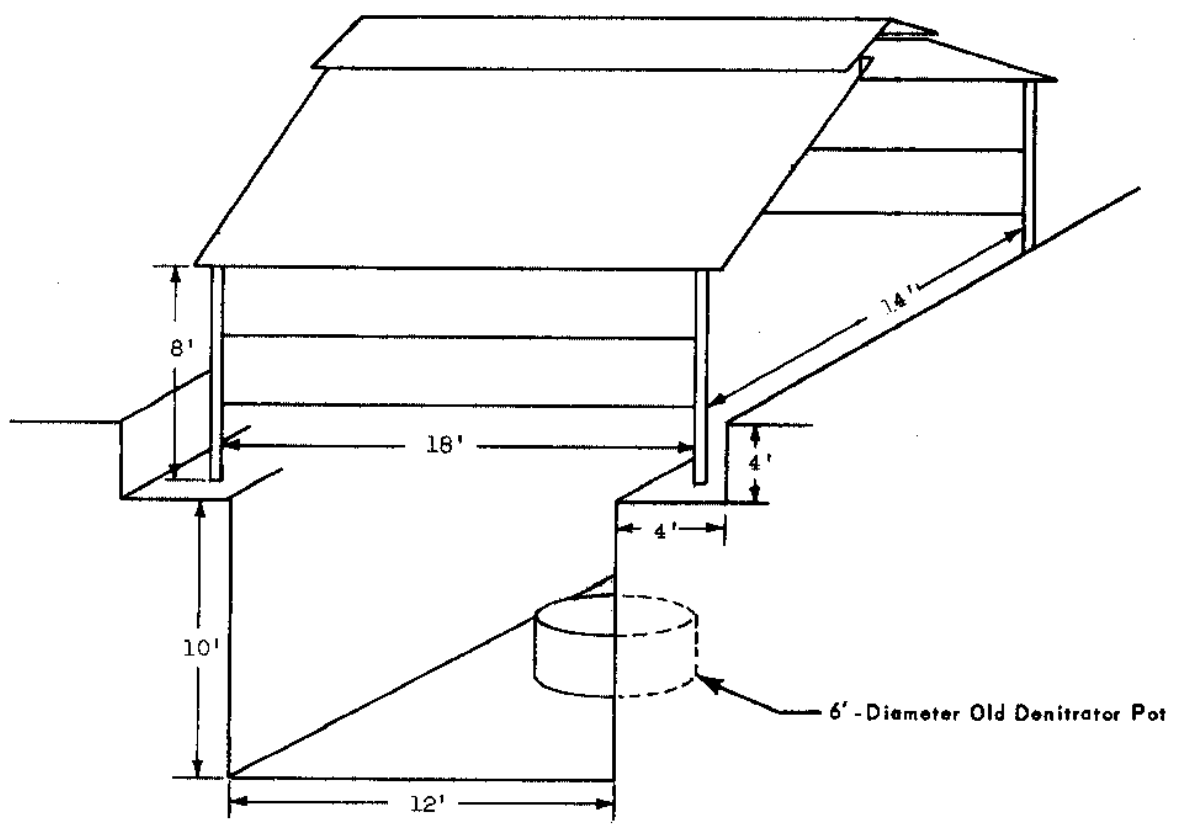

FIG. 2 SOLVENT BURNING FACILITY 
was constructed and covered with a sheet metal roof. Large batches of solvent were burned, but the pan developed holes from corrosion after only 6 or 7 days of burning. Heavy blowing ralns may have been responsible for early fallure of the pan. Currentiy, longltudinal halves of 400-gallon cylindrical mild steel tanks are being used.

Burning pans are emptied into the ditch bottom by a crane when they are about half fllled with the thick, tar-like residue that remains after burning. The residue, which is relatively insoluble in water, is then covered with dirt and sometimes with a layer of bentonite. Use of bentonite as an "umbrella," or a barrier to water seepage, was developed in 1961-62. When a burning pan is discarded, it is usually burled in the ditch.

\section{CONTAMINATION CONTROL MEASURES}

When solvent was first burned (in 1956), an arbitrary limit of 100 counts/(min)(mI) of gamma activity in the solvent was adopted; but as the program progressed, the limit of activity was progressively increased; by 1957, solvent having up to 10,000 counts $/(\mathrm{min})(\mathrm{ml})$ was burned.

Analyses of the smoke and gases from the burning pan initially showed that concentrations of radioactivity seldom exceeded the Radiological Control Gulde (RCG) limits for ${ }^{108} \mathrm{Ru}$, normally the predominant fission product. Formerly, when gamma spectrometric and chemical separation analyses were not avallable, procedures required adherence to the RCG for ${ }^{90} \mathrm{Sr}$, which has the most restrictive limit of any of the fission products concelvably present (the limit for ${ }^{90} \mathrm{Sr}$ is only one-sixth of that for ${ }^{108} \mathrm{Ru}$ ). Later, after 1t was recognized that radioactivity in smoke is greatly diluted within a short distance from the burning site, procedures were modifled to permit burning of relatively high-level solvent by establishing the entire burlal ground as as assault-mask area while solvent is being burned.

Now, solvent is ignited at the end of the day shift and normaliy burns without monitoring until the quantity in the feed tank, usually 500 to 1000 galions, is exhausted. Under this procedure, solvent having up to 11,000 counts $/(\mathrm{min})(\mathrm{ml})$ of beta-gamma activity* has been burned without spreading significant amounts of contamination, despite the fact that some samples of undiluted smoke show concentrations up to fifteen times higher than the RCG limit for ${ }^{9} \mathrm{Sr}$.

\footnotetext{
* 11,000 counts $/(\mathrm{mIn})(\mathrm{ml})$ of ${ }^{108} \mathrm{Ru}$ gamma activity = approximately 1.9 millicuries ${ }^{108} \mathrm{Ru}$ per gallon. The conversion factor varles for different radiolsotopes, because it depends upon the counting efficiency of the instrument used. Typical counting efficiences are: ${ }^{108} \mathrm{Ru}, 1.0 \% ;{ }^{137} \mathrm{Cs}, 1.9 \% ;{ }^{85} \mathrm{Zr}-{ }^{85} \mathrm{Nb}, 2.2 \% ;{ }^{134} \mathrm{Cs}, 4.9 \%$.
} 
On two occasions, before it was known that water in the burning pan should be avoided, contamination was spread to vegetation in the immediate area, but was of a low level and disappeared with the next rains. Apparently, water bolls below the solvent and entrains contamination in the steam, whereas burning in the absence of water is relatively quiescent at the liquid surface and entrains little or no contamination. No cases of personnel contamination resulted from these incidents.

\section{QUANTITIES HANDLED}

Beginning with the first shipment of spent solvent ( 28,000 gallons) in August 1955 and extending through February 1964, the burlal ground has recelved from the separations processes about 289,300 gallons; of this, 170,000 gallons were burmed, leaving 114,600 gallons of solvent In storage and 4,700 gallons of water in retired Tanks 1 through 4. This water will eventually be pumped out and transported to aqueous waste storage facilities.

In addition to process solvent, 36,000 gallons of $35 \%$ TBP w1th smali amounts of natural uranium ( $5 \mathrm{gm} / 11 \mathrm{ter}$, maximum), but no fission products, were recelved from an of $f-s 1$ te contractor. Th1s solvent was piped directly to four 1500-galion semlcylindrical pans from the tank cars in which 1t was recelved. Batches of up to 6000 galions each were burned producing large quantities of black smoke, but very little residue.

Flgure 3 shows the volumes of spent solvent that were received, stored, and burned from startup in July 1955 through February 1964. For some periods, data were not avaliable and had to be interpolated; where a discrepancy was found between volumes recelved and stored or burned, the volume stored was taken as the basis for correction, except when another value was clearly more accurate. All solvent recelved through 1959 was $30 \%$ TBP; but recently, the enriched uranium process produced some quantities of $3.5 \%$ and $7.5 \%$ TBP-kerosene solutions.

\section{ATTEMPTS AT IMPROVEMENT}

\section{Purification and Reuse}

Attempts have been made to recover the solvent by distillation. This technique was finally judged to be economically unsound even if the solvent were reusable, and there was good reason to doubt that it could be reclaimed. 
Thousands of Galions

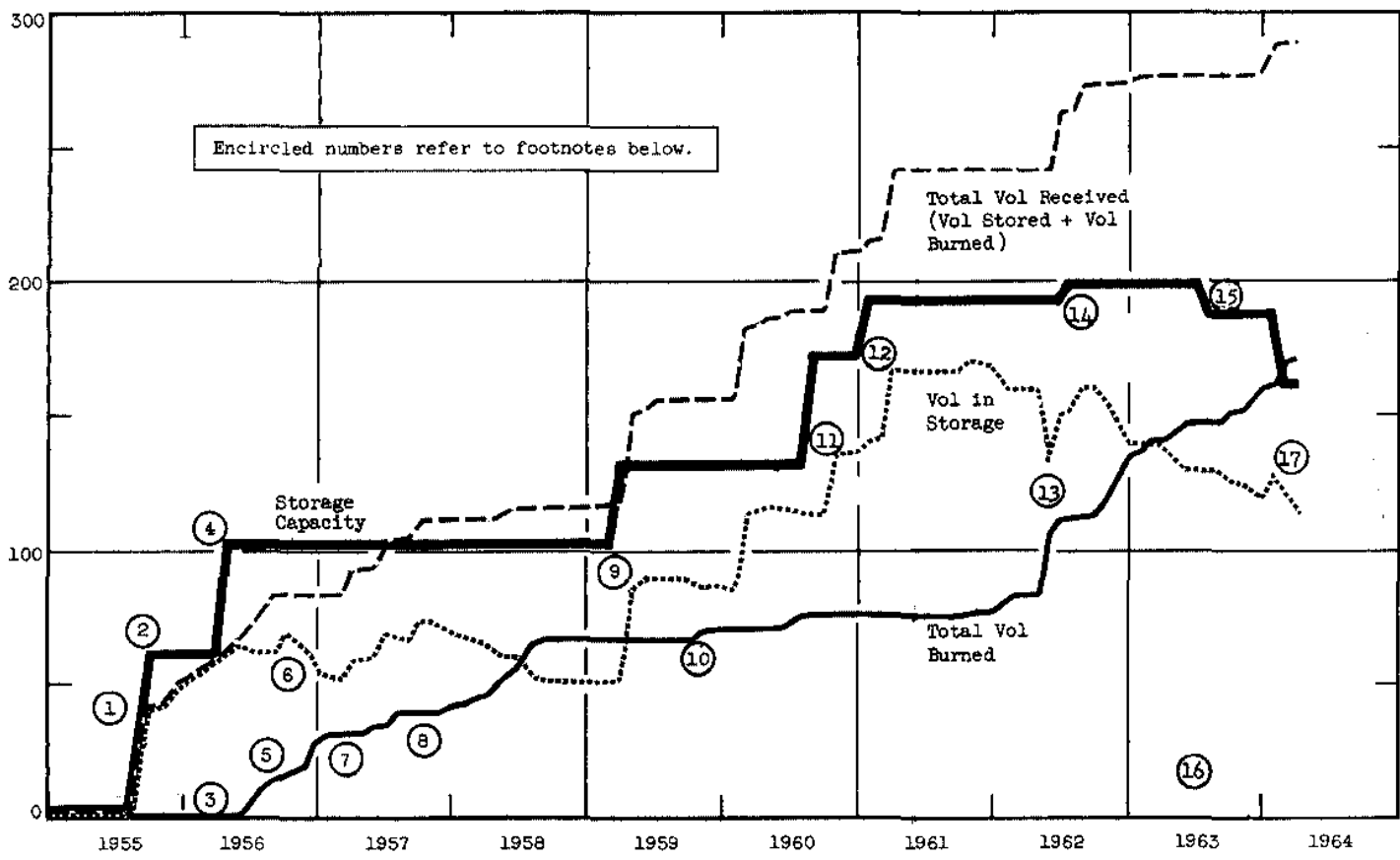

1. August 1955: Installation of Tanks 1-4, on emergency bas1s; capac1ty 36,300 galions.

10. September 1959: Installed new solvent pump w1th higher capac1ty.

2. September 1955: Installed Tank 5, 24,600 gallons capacity.

11. October 1960: Installed Tank 13, 13,800 gallons capacity, and Tank 14, 27,200 gallons cepac1ty.

3. February 1956: Flrst recorded solvent burning; gamma activity of $100 \mathrm{c} /(\mathrm{min})(\mathrm{ml})$ in solvent; no release of contamination.

12. January 1961: Installed Tanks 15 and 16, 10,300 gallons capacity each.

4. April 1956: Installed Tank 6, 24,600 gallons capacity, and Tanks 7 and $8,7,800$ gallons capacity each.

13. May 1962: Burning procedure changed to perm1t continuous buming; highest quant1ty of solvent burned in any month on record: 22,300 gallons.

5. May 1956: Installed larger ( 1 inch) line from feed tank to buming apparatus; increased burning rate to 200 to 250 gallons per day.

6. August 1956: Installed concrete shlelding wall at solvent tank truck unloading facility.

7. February 1957: Bumed high-act1vity solvent (radioactivity 100 times greater than previous limit) without incident.

8. November 1957: New solvent pump installed.

14. July 1962: Installed Tanks 17 and 18, 3,200 gallons capacity each.

15. June 1963: Tank 1 emptied and retired in place.

16. July 1963: New burning ditch opened, parallel to the old one; old ditch closed.

17. February 1964: Tanka 2, 3, and 4 emptled of solvent and retired in place; inventory corrected for total of 4,700 galions of water left in these and Tank 1.

9. March 1959: Installed Tanks 9 through 12, 7,400 gallons capac1ty each.

FIG. 3 SPENT SOLVENT IN BURIAL GROUND 
A solvent-steam flash vaporlzer was developed by the Savannah RIver Laboratory, but the estlmated cost of a plant unit was about $\$ 300,000$, and there was insufficlent assurance that the product would be reusable. Distillation at atmospheric pressure was cheaper, but higher temperatures in this process increased the degradation so that the product was not reusable.

\section{Purlfication for Unrestricted Burning}

Limited tests were made of an inexpensive apparatus for atmosphericpressure distillation of waste solvent solely to reduce 1 ts radioactivity before burning. Decontamination factors of 30 to 2000 were measured (these factors were limited by counting sensitivity w1th the distillate). Some TBP was distilled along with the kerosene. Results of these tests are given in Table III.

\section{TABLE III}

Distillation of Spent Solvent at Atmospheric Pressure

$\begin{array}{cccc}\text { Alpha } & \text { Beta } & \text { Gamma } & \\ \text { Activ1ty, } & \text { Activ1ty, } & \text { Activity, } & \text { TBP, } \\ d /(m I n)(m I) & c /(m I n)(m 1) & c /(m I n)(m I) & \text { wt \% }\end{array}$

\section{First Test}

Feed content Distillate content Decontamination factor

\section{Second Test}

$\begin{array}{rrrr}194 & 8.04 \times 10^{3} & 1.19 \times 10^{3} & 26.0 \\ 2 & 4 & 4 & 5.3 \\ 97 & 2 \times 10^{3} & 3 \times 10^{2} & \end{array}$

202

6 34

$$
1.0 \times 10^{3}
$$$$
3
$$

$3.3 \times 10^{2}$

$\begin{array}{rl}173 & 5.7 \\ <1 & 3.4\end{array}$

$>173$

It was concluded that there is no economic incentive to abandon the present burning process or supplement 1t by distillation, but that efforts to improve burning techniques should be continued. 


\section{Burning Methods}

Burning spent solvent poses two problems: (1) smoke and (2) dispersal of radioactivity. When smokeless burning is attained by efficient burner design, retention of activity is difficult. Some quiescent surface burners entrain very little radioactivity, but usualiy have too little capacity for this application. Other burners that use feed injection and forced alr have high capacity, but entrain contaminants that must be filtered or scrubbed from their stack gases.

Attempts to improve burning methods, thereby abating the smoke and minimizing the release of contamination, included these tests:

- A salamander bumer (see Flgure 4) completely eliminates smoke, but has very limited capacity and no provision for removing the residue. Ten or more of them would probably have to operate $\mathrm{s} 1 \mathrm{x}$ to elght hours to burn 100 gallons. However, if the problems of resldue removal and scaleup of this burner could be solved, it could be useful. Tests of this burner gave a decontamination factor of over 1000. Development work on this type of burner has been discontinued because the burner's capaclty is too low for this application.

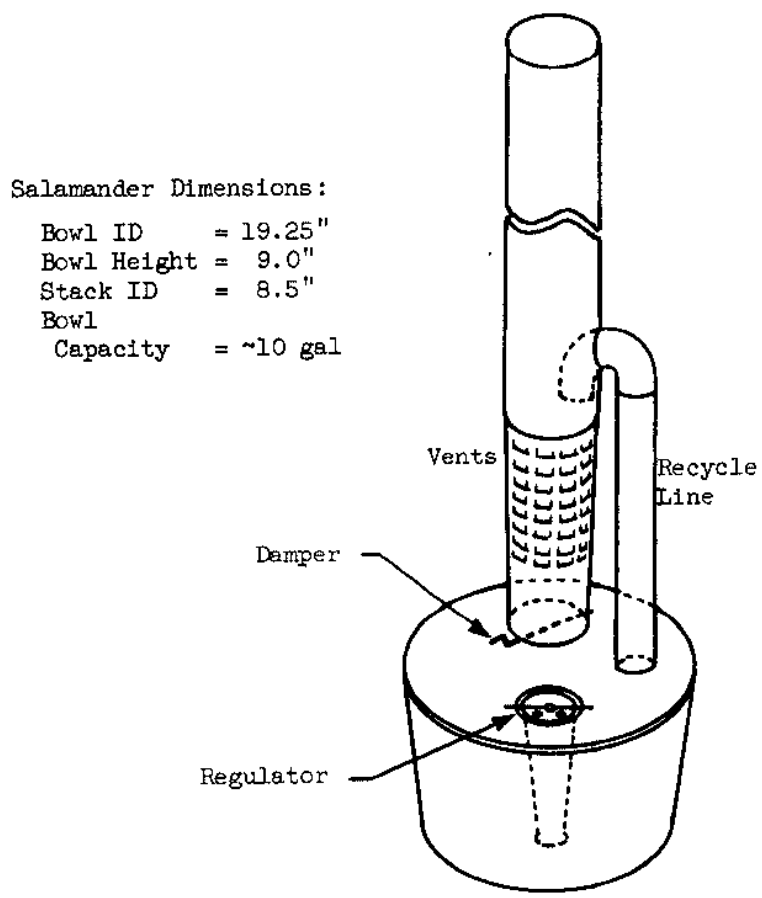

FIG. 4 OIL-BURNING SALAMANDER 
- Underground burning was tried with the expectation of getting better oxidation of unburned carbon in the smoke. A burning pot was set in the bottom of a 10-foot-deep shaft, which was intersected by an a1r-supply shaft near the bottom (see Figure 5). Cleaner burning resulted only at burning rates too low for practical consideration ( $2 \mathrm{gal} / \mathrm{hr}$ ), so this method was abandoned.

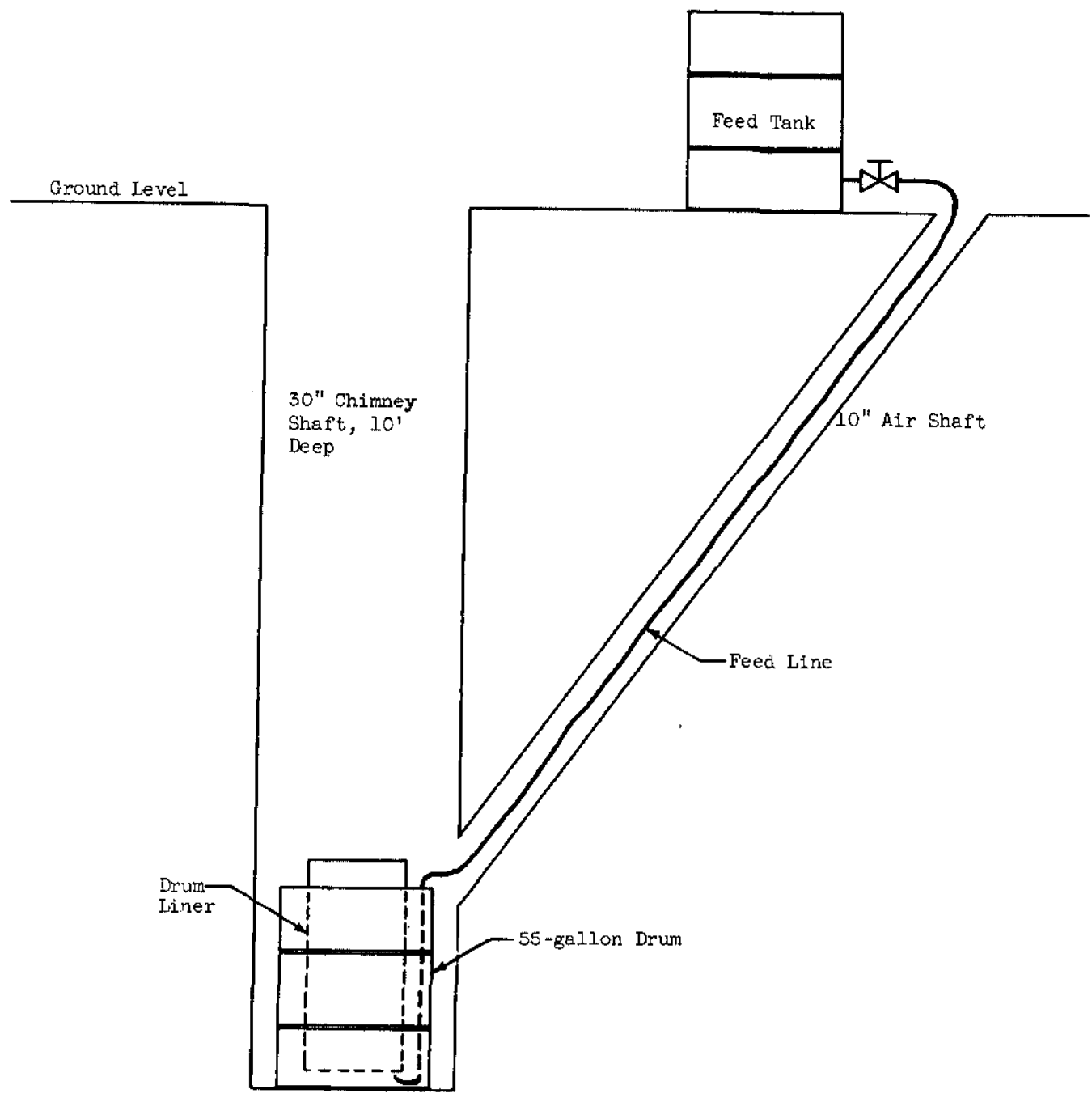

FIG. 5 APPARATUS FOR UNDERGROUND BURNING TEST 
- When some commercial speclalists in waste incineration were contacted, they stated that the smoke problem and other pertinent problems could be readily abated, but that removal of radioactivity from combustion gases would be a problem. They proposed a burner that was fed by a high pressure spray, which would entrain most of the activity in the combustion gases. This technique would require filters and/or scrubbers, and would create additional problems in supply and disposal of scrubbing fluld and filters, but would provide high-volume solvent disposal without smoke.

\section{Residue Disposal}

Efforts to improve containment of contamination in the residue from the present burning process have been spearheaded by the development of the bentonite "umbrella". This technique has been used on some residue burials, but is difficult to assess because there are no nearby monitoring systems and there has been no indication of leaching from solvent residue, with or without the "umbrella." Contaminants leached by ground water could be in aqueous solution and subject to ion exchange with the soll, as are those in the seepage basins. 